\title{
Belief System
}

National Cancer Institute

\section{Source}

National Cancer Institute. Belief System. NCI Thesaurus. Code C16330.

Faith based on a series of beliefs but not formalized into a religion; also, a fixed coherent set of beliefs prevalent in a community or society. 